\title{
SOCIAL DETERMINANTS OF CRIME AND HATRED INCIDENTS AT MASS SPORTS EVENTS IN POLAND
}

This article presents issues related to crime and hatred occurring at mass events organized in Poland in recent years. It is a continuation of the authors' considerations regarding this relatively narrow field of security which generates a need to involve significant numbers of police officers. The police are required not only to ensure these events go as planned, but also to eliminate dangerous instances of crime and hatred, which have so far been an 'inseparable element of the landscape' in certain cases. The aim of this article is to conduct a quantitative analysis of these negative phenomena and try to determine their causes, and present proposals for future activities. The basic research problems involve finding answers to the following questions:

- Did the determination of police in ensuring the safety of the EURO 2012 final tournament calm the mood and improve security of mass events?

- What is the current scale of crime, hooligan acts and collective violations of security and public order in relation to mass events organized in Poland today?

- Are the solutions in this area systemic, durable and consistent?

The authors' experience, analyses of the state of security, discussions with police officers and media reports on the subject, identified as crime and hatred incidents which occur in connection with mass events organized in Poland, have led to the hypothesis that, despite wide-ranging activities by public security authorities, crime and deeprooted hatred for members of different sports clubs and ideological opponents, continue to be the hallmark of the hooligans attending mass sports events in Poland. Methods characteristic of theoretical studies have been employed developing this study, as well as the results of surveys conducted in 2014.

\section{CLASSIFICATION OF PARTICIPANTS OF MASS EVENTS AND DESCRIPTION OF TYPICAL BEHAVIORS}

Mass events ${ }^{1}$ have always electrified large numbers of people, although certainly not everyone and not to the same extent. People's interest is often manifested by being

${ }^{1}$ The term was introduced to Polish legislation in 1997, and then its scope was modified as a result of changes in subsequent versions of the provisions on the security of mass events in Poland. 
ready to express their support, or actively supporting their teams in different ways, which has ultimately made it possible, and relatively easy to distinguish specific groups among the participants of mass events. Even people who are not directly related to sports or those completely uninterested in sporting emotions are able to classify some participants of these events. Without a doubt, the largest group among them are 'average fans,' who are often referred to as 'real fans' in the literature on the subject, 'real supporters' and 'real spectators.' These terms characterize those people who, albeit sometimes quite vigorously, cheer for their individual or collective idols in a manner consistent with the law and regulations of the venue. This group of fans appreciates the emotions that accompany such events, the level of sporting competition, the atmosphere in the audience, and, ultimately, victory, which gives them satisfaction with participation in the event and inspires admiration for the winners. Referring to these fans as 'real' suggests that there are also participants in mass events who can be described as 'false' fans. There are indeed, although they form a small, specific community that nevertheless generates considerable dangers and, in many cases, requires significant security forces to ensure order both inside and outside of the stadium. This groups is also referred to as 'hooligans' ${ }^{2}$ [Pl.: chuligani] or 'hardcore fans' [P1.: kibole] (Zalewska, 2010: 303), sometimes they are also called 'pseudo-fans' [P1.: pseudokibice]. In the literature they are described as "men in the 21-26 age bracket, mostly unmarried, with secondary education, often without a criminal record. They are characterized by a sense of impunity, and the narcotics and alcohol they use often stimulate aggression" (Chlebowicz, 2009: 231). Each of the above names given to them raises pejorative connotations and refers to a negative set of socially unacceptable properties. Generally, these are people, or groups of people, who share a common passion, sometimes love for their idol or, more often, for the team, but the level of negative emotions - often hatred and destructive behavior - prevails over common sense and exceeds applicable legal and social norms. In extreme cases, a sports event is not the reason that brings them to the stadiums, more important are their opponents, namely the fans of the opposing team and, perhaps above all, the security and police officers guarding the security of this mass sports event. According to Mikosza, "what is characteristic of most such groups is that many members are dressed in sports clothes: running suits, sneakers, T-shirts of their respective clubs, hats, etc. However, the club scarf is the most important thing for them. They have a peculiar sense of honor which characterizes only this social group. Their honor is preserved when they fight with the police and other fans; they can never retreat without a fight" (Mikosza, 2010: 300-301). Their level of fanaticism can lead to extremely irresponsible behaviors during sports events, including assaulting security and police officers, fights, assault, pitch invasions, use of illegal pyrotechnic devices, etc. More dangerously, these groups of fanatical supporters neither start nor finish their activities in the stadiums; they have long since moved

Currently, Art. 3 of the Law on the Security of Mass Events stipulates that mass events should be understood as arts and entertainment mass events, and sports mass events, including football matches. Ustawa z dnia 20 marca 2009 r. o bezpieczeństwie imprez masowych, Dz. U. 2009, No. 62, item 504 as amended.

2 The term 'hooligans' comes from the name of Edward Hooligan, a member of a wealthy Irish family who was the leader of a London gang at a young age. 
outside them. They can arouse fear and dismay during their collective trips to sports arenas, commit theft, ${ }^{3}$ assault and battery, or even kill their enemies in the name of specifically conceived principles and the need for revenge. Lipczyński presents a similar opinion when he argues that "the aggression emerging during football matches quickly began to be called hooliganism. This phenomenon occurs not only during football matches (e.g. assaulting other spectators and the police, pitch invasions, clashes with security forces), but also when traveling to the match and back" (Lipczyński, 2007). The attitudes presented by these fanatical groups are based on disregarding existing legal norms; what is more, such behaviors are most appreciated and desirable in these circles (Kwaśniewski, 1976: 203). These hierarchically organized groups divide tasks among their members and are characterized by contempt for the law and law enforcement, deep hatred for the enemy and the requirement to take revenge (for example, if their club colors - symbolized, for instance by the club scarf - have been desecrated), and refusal to cooperate with law enforcement agencies in any way. All this means that modern groups of football hooligans display some of the characteristic features of the world of organized crime. Thus both the leaders, and in some cases other charismatic members of such groups, may create similar structures based on mafia principles of omerta and vendetta ${ }^{4}$ or they may be easily absorbed by the world of organized crime. T-shirts with their principles and the prohibitions to break them are 'proudly' worn by some members of these circles.

Figure 1. Samples of garments worn by the groups of football hooligans

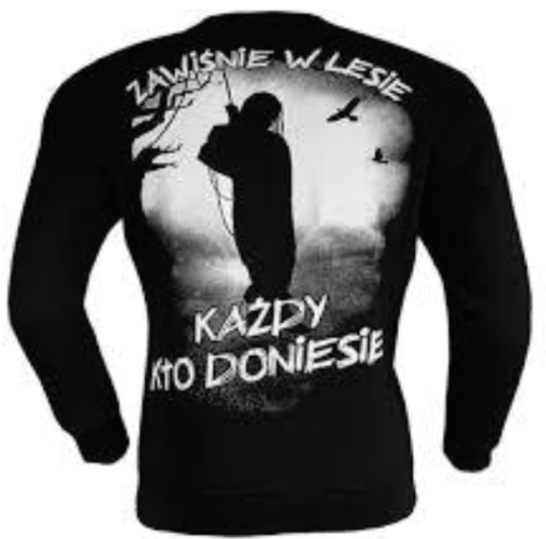

"A NOOSE FOR EVERY SNITCH"

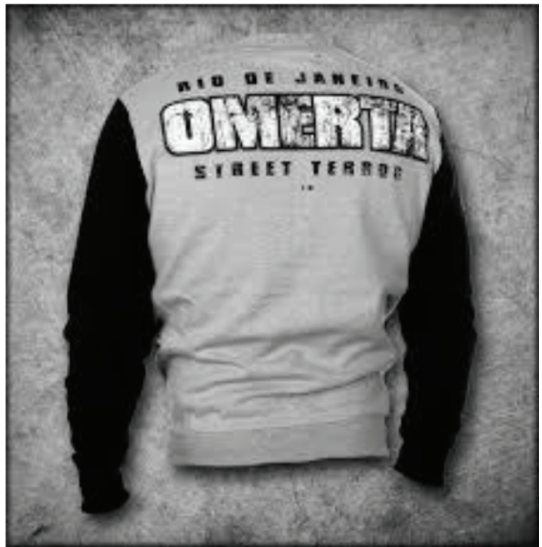

Source: Website of the "Madman" store with casual, patriotic and fan clothes: https://madman.pl.

${ }^{3}$ In the colloquial speech of police officers safeguarding mass events in Poland, such organized thefts, which quite often take the form of collective intrusion of hooligans into shops, gas stations or other places of trade in which the perpetrators behave aggressively and do not pay for the products they take, are called 'promotion.'

${ }^{4}$ Vendetta - revenge; next to its regular dictionary meaning, this term is characteristic of mafia circles. This is one of the rules demanding revenge, often very bloody, on an enemy criminal group or a member of one's own group in retaliation for breaking internal rules. Omerta - silence - inside mafia, this term is understood as a conspiracy of silence, whereby any contact with law enforcement officials is prohibited, to protect information on how the organized criminal group operates. 
A similar view on hooligan behavior evolving towards organized crime is expressed by Pływaczewski, who argues that "until recently, traditional crime accompanying some football meetings was associated only with classic stadium hooliganism. The law was most often violated due to the use of violence or vandalism. Cases of organized crime infiltrating what is called 'stadium crime' were reported as early as in the 1960s by the police in some Western countries; initially they were not treated as something that required further action or the implementation of specific preventive programs. It was not until drug gangs started penetrating into football supporter circles generating undesirable consequences that the police and authorities realized it was necessary to take firm preventive actions, primarily due to the increasing role of organized criminal structures in these circles" (Pływaczewski, 2010: 21).

\section{HISTORY AND DEVELOPMENT OF THE 'FOOTBALL HOOLIGAN' SUBCULTURE}

The organization of the Polish part of the 2012 UEFA European Championship, known as Euro 2012, enforced taking specific and multi-faceted steps with the overarching objective of ensuring the full security of this sporting event. Although the issues of violence, hatred and crime associated with mass events were not 'discovered' in Poland just before the organization of Euro 2012, at that time they were extensively presented in the media as extremely disturbing and threatening general security. Such behaviors have had a long history. The phenomena based on a specific subculture $^{5}$ developed in Poland as early as in the 1970s, following English models, and relatively quickly 'found themselves at home' among some fans of football clubs, particularly at the highest levels of competition. Perhaps this negative behavior became rooted in Poland at such a rapid rate due to the limited range of possible entertainment targeted at young people, who adopted these new social currents. "At that time, radio and television were the main sources of entertainment which made young people fascinated with the mass culture of 'the West.' Young people were so determined to change the 'gray' reality that they won the battle for their own style, although it did not always constitute an acceptable social pattern" (Sadowska, 2010: 169). It was in the 1970s that organized sports fan movements emerged in Poland. The foundations for future fan clubs appeared then. Small groups of fans began to wear their club colors and cheer their teams during the matches they played, whether at 'their' stadium or during trips to other locations. Over the years, the first friendships were struck between supporters of individual clubs (known as 'consents' [Pl: zgoda]). Each larger group of supporters already had their main opponent or opponents (known as 'scythes' [Pl: kosa]) (Piotrowski, 2000: 30). Today, these friendships and hatred, sympathies and hostility are no longer only domestic and have become international. Informal supporter groups have been fighting

${ }^{5}$ Subculture [P1.: subkultura] is defined, e.g., as a kind of subculture [P1.: podkultura] with a set of symbolic and axiological references which determine the distinctiveness of a given group from other social groups. B. Preis Subkultury młodzieżowe, Katowice 2010, p. 9. 
with one another, also in the form of arranged fights. ${ }^{6}$ These bloody fights are about glory and domination or, in other words, about acknowledging the superiority of the most formidable, most efficient and most dangerous fighting squad ${ }^{7}$ in the country. With time, ideologies, and thus ideological opponents, have emerged. In the late 1970s offensive slogans could be seen on the walls which referred to some football clubs as 'Jude;'8 this expressed contempt towards the opponents from hostile football clubs, and was also associated with intolerance and hatred towards the Jewish culture among other things. Strong anti-Semitic, extremely nationalist and even fascist elements among football hooligans appeared on Polish stadiums alongside the development of the skinhead subculture in the 1970s and intensified in the 1990s. To this day, members of these extremist groups have been proclaiming fascist slogans; they have also declared 'war' against people of different skin colors and faiths. It was out of this subculture that future fighters emerged in highly dangerous groups of hooligans, who blatantly violate the law in and outside of stadiums, and are also responsible for assaults in the name of the ideology they profess (Mikosza 2016: 137). According to Pływaczewski, "one can easily note that the crimes have been committed by hooligans under the influence of strong aggression triggered by their enormous hatred towards supporters of other teams. However, the language of hatred and aggression (hate speech) that is acknowledged as a specific means of social communication was, is and will be used as an important tool of ideological struggle" (Pływaczewski, 2012: 38). We are therefore dealing with deeply rooted pathology, understood today as phenomena generated by football hooligans but not approved of by the rest of society. These processes cause behaviors that profoundly deviate from the standards within a given community, are condemnable, and exceed admissible patterns, thereby threatening the established course of social life. "This is not only about the behavior of an individual or a group, but also about the disintegration of institutions, weakening of all control mechanisms (both formal and informal), the volatility of the assessment criteria, and about the appearance of behavior patterns that are divergent from patterns recognized as acceptable" (Kroczek, Bińkowska, 2014: 139). In the literature on the subject, a new term has appeared over time that identifies and defines this phenomenon as 'stadium crime,' and is often used interchangeably with 'stadium hooliganism,' though not quite rightly, as crime means a set of behaviors involving violations of criminal law, and hooliganism does not always involve committing crimes. After all, it can also involve various minor of-

${ }^{6}$ An arranged fight [P1.: ustawka] is a deliberate meeting of two groups of fans who put up a regular fight. Fights are organized outside of the mass event area, preferably so as to prevent law enforcement authorities from learning about them; usually by means of online posts. Often, as part of internal codes, the number of hooligans taking part in a fight is determined, e.g. 5, 10 or 20 on each side. There are also fights where there is no limit on the number of participants, referred to as 'a gang vs. a gang' [Pl.: banda na bandę].

${ }^{7}$ A fighting squad [Pl.: bojówka] is a group of hooligans specially trained for fights between feuding clubs in arranged or random fights. Squads are characterized by their exceptional brutality and ruthlessness. Their members are ready for bloody fights and even potentially killing their opponents.

${ }^{8}$ Literally: a Jew; for football fans the personification of an ideological opponent. Anti-Semitism among the groups of supporters concerned has unfortunately been a long-established sentiment in Poland. 
fenses or demonstrating frustrations and releasing negative emotions without breaking the law. In the event of a breach of criminal law, hooligan behavior is classified as a 'hooliganism offense' defined in Article 115(21) of the Penal Code as an offence involving a deliberate assault on health, on freedom, on virtue or bodily integrity, the common safety, on state or local government activities, on public order, or the intentional destruction, damage of another person's property, or rendering them unfit for use, if the offender acts in public, and without cause, or with an evidently trivial reason, showing a blatant disregard for the law (Ustawa, 1997). The target of the assault is specified in this provision very broadly and includes not only people or, more precisely, their health, freedom, virtue or bodies, but also state and local government institutions, public order and property. It should be noted, however, that only such actions that demonstrate blatant, ostentatious contempt for the law are described as hooliganism, as well as when the behavior of perpetrators is often referred to as triggered by base motives. The above-described behavior closely resembles the attitudes presented by numerous groups of football hooligans, for whom breaking legal norms is simply a lifestyle.

Stadium crime does not refer solely to criminal acts committed at stadiums and other sports facilities, thus limiting the scope of these negative phenomena. Today, 'stadium crime' occurs also, or perhaps mainly, outside sports facilities and involves theft, assault, various hate-inspired acts, drug trafficking, participation in organized crime groups, and even manslaughter.

\section{EFFECTIVENESS OF PREVENTITIVE MEASURES TAKEN - STATISTICAL EVALUATION}

All cases of pathological behaviors associated with hate speech, crime and antisocial behavior in the groups of football hooligans, even when scarce, demand a thorough analysis and forecasting further development, in order to prevent them as effectively as possible and change this highly negative image. However, the question remains of whether the current measures proposed to combat and prevent violations of security and public order are sufficient to ensure a secure future, calm the mood in the most antagonistic groups of Polish stadium hooligans and limit hatred, aggression and violence among them.

A few years ago, the authors of this article would have argued that the intensified activities of the services of security and public order, focused on this aspect of security, particularly in the period immediately preceding the organization of Euro 2012 European Football Championship, would produce certain outcomes in the near (although unspecified) future. ${ }^{9}$ Police activity before Euro 2012 focused on the elements related to improving the security of mass events in Poland, with particular emphasis on football matches. Importantly, extremist football fans cause the greatest threat to the security of sports mass events, not only in Poland, and represent the greatest challenge and

${ }^{9}$ In 2014, one of the authors conducted research in a group of nearly 350 police officers in Poland; the majority of them were of the opinion that the tactical solutions applied by the police immediately before the championship would result in improved security during mass events in the future. 
threat to the participants of such events and the law enforcement officers protecting them. The police were forced to intensify their activities in part due to pressure from politicians and the police authorities (Ministry of the Interior), UEFA representatives and the media, and proposed a package of measures to improve the situation. A special catalog of tasks and methods was adopted, which were characterized by ultimate determination in achieving the final goal of ensuring the security of Euro 2012. In order to improve the status quo at the time, the following shortcomings identified by the General Police Headquarters had to be removed:

- ineffective recon in hooligan circles;

- lack of involvement of event organizers, clubs, and the Railway Protection Guard in securing the journeys of football fans, thereby transferring all responsibility for ensuring security to the police;

- improper and passive behavior of the services of event organizers;

- escalation of hooligan behavior in sports other than football;

- demonstrable use of pyrotechnics without penalty;

- demonstration of attitudes by sports supporters in order to achieve political effects;

- conservative operation of intervention sub-units. ${ }^{10}$

Given the range of the above-presented faults, police commanders were tasked with the immediate implementation of the following strategic directions of action:

- involving operational services (including the Central Bureau of Investigation, later - Central Bureau of Investigation of the Police) in disclosing the perpetrators of violations of the law and arresting them immediately after any incidents; ${ }^{11}$

- deployment of forces and resources to ensure immediate action;

- monitoring the process of safeguarding the event and enforcing the response of security services to incidents;

- initiating meetings with representatives of clubs, football fans and event organizers;

- conducting detailed reconnaissance in hooligan circles;

- using police from anti-terrorist subunits and intervention groups established to stop aggressive fans;

- ensuring rotation among policemen-spotters; $;^{12}$

- trying to detain perpetrators immediately after an event in order to avoid a lengthy process of recognizing and identifying them;

${ }^{10}$ Material from the meeting of the Deputy Chief of Police of July 13, 2011 in Sułkowice prepared by the Main Staff of the General Police Headquarters (author's archive).

${ }_{11}$ To investigate the most dangerous structures of organized hooligan groups, the Central Police Investigation Bureau was involved, which was ordered to analyze the categories of crimes committed by persons associated with these circles. In Poland, the CBIP is primarily responsible for identifying threats related to organized crime.

${ }^{12}$ The function of spotters has considerably evolved in Europe over the last 20 years. It is not the same in all the countries that have decided to apply this solution. In general, a spotter today is an overtly operating policeman who is well known to the supporters of a given football club and cooperates with them in the field of broadly understood security. When necessary, spotters can discipline aggressive supporters, but they can also assist the club when organizing trips to matches. Spotters also ensure that football supporters observe and enforce the law and perform tasks in the field of crime prevention. Introducing the function of spotters was a key project implemented during the Euro 2012 Championship, which, in the opinion of many UEFA experts, contributed to ensuring the safe conduct of the championship and a good image of Polish law enforcement officers. 
- attempting to initiate and motivate activities by organizers of events - responding to their passivity and incorrect conduct (KGP, 2011).

It seemed ${ }^{13}$ that the measures taken would be effective not only during the finals of Euro 2012 in Poland, but would also contribute to improving safety in Polish stadiums after the championships, including in particular curbing the number of crimes committed by football hooligans. This could be achieved provided that the solutions and assumptions adopted would be continued and law enforcement officers would be committed to recognizing and preventing such behavior. Long-term prevention programs were also proposed to educate future generations of supporters in the spirit of respect for the law and the principles of tolerance.

Today, this conviction that the preventive measures applied are effective, including the effectiveness of prevention programs expected to bear fruit in the future, is mitigated due to a series of tragic events involving groups of outrageously irresponsible hooligans that occurred after 2012. The events, which were widely described and commented in the media in 2013-2018, are an example of this. The first group of events occurred in Krakow, a city in which the supporters of two feuding football clubs, Wisła and Cracovia, have long been fighting a ruthless battle they call the 'Holy War." ${ }^{14}$ One event concerned a hooligan brawl: "The District Prosecutor's Office for Kraków Krowodrza accused four young men, football hooligans supporting Cracovia, of participating in the beating up of three supporters of Wisła. The victims sustained injuries from having been hit with a metal pipe and beer bottles thrown at them. Two football hooligans are in custody. They are facing up to 10 years in prison" (Kraków: Nasze miasto, 2015). Another event occurred in the same city. In this case, a machete was used instead of a pipe "on Na Wrzosach, a quiet street with detached houses. In addition to houses and several small businesses, the street borders a playground and the grounds of the 15th Comprehensive High School. It was here that, on Tuesday evening, a group of men attacked a 26-year-old man with machetes" (Krakow: Nasze miasto, 2013). Unfortunately, machete attacks on the supporters of feuding clubs are not isolated cases in Poland. In this way, those who presented a special threat have been 'liquidated.' The following case is slightly different, however, as it shows the ruthlessness of these fanatical groups also towards their idols. In their own opinion, football hooligans as 'the only fair and infallible ones,' have the right to judge everything and everyone, only their ideology is rightful, and punishments have to be imposed. After Legia Warszawa was defeated in a match with Lech Poznań in the fall of 2017, an exceptional, albeit not unprecedented, event took place: "the leader of the Legia supporters entered the coach carrying the players and 'invited' them outside. The players thought they were facing an unpleasant conversation, but they were immediately attacked. The hooligans rushed at them, hitting them on the backs of their heads, and slapping them in the face

13 The author's statements are based on his own knowledge and observations, because in 20052007 and 2010-2012 he was the Deputy Chief of the Police and was co-responsible for ensuring the security of mass events, including Euro 2012.

${ }^{14}$ Louis Gintel, a Cracovia player, was the first to use this phrase inviting his club mates to the derbies. "Let's go to this holy war, gentlemen," he said then, without realizing that this simple sentence would go down in the history of Polish football. At that time, derbies involved native Cracovians - people for whom the attachment to club colors was a true value, http://www.czasfutbolu. pl/derby-krakowanihistoria-prawdziwa/, Czasfutbolu 2012 (07.02.2018). 
so that they felt humiliated, but sustained no serious harm. Even the assistant coach Aleksandar Vuković 'got it.' The new Legia coach Romeo Jozak who was standing by came out unscathed. The event lasted around 10 minutes. Then the players went home thinking not only about the defeat but also about the events at the parking lot. The words of the attacking group were ringing in their ears: 'If you play like that in the next match, we will come again"” (TV Republika, 2017).

The above events involved only hooligans who considered themselves the true supporters of their football clubs. In fact, they are often 'thugs' that pose a huge threat to public security and order, not only in relation to mass events. The biggest challenge for law enforcement is the security of football league matches. Extremist groups of hooligans, as exemplified above, are characterized by exceptional aggression and brutality. Hooligans' hatred towards everybody they identify as opponents is so enormous that they can openly commit crimes without fear of legal consequences. What is more, such extreme attitudes create the future leaders of these groups. Without the slightest doubt, these particular behaviors have to be monitored and pursued by police officers consistently and determinately.

Referring to football hooligans' behaviors as 'stadium crime' implies that we are dealing with specific criminal acts committed by these groups. Since these crimes (only those that have been reported) are recorded in police statistics, they can be analyzed and considerable threats in this area can be presented.

The below analysis is carried out on the basis of an annual report on the state of security of mass events prepared by experts from the Office of the Main Staff of General Police Headquarters in Warsaw. The authors of the report have employed the model whereby the most important issues related to the security of mass events are presented including the division into categories following from the classification stipulated in legal regulations. Therefore, the data in the report is related to mass events in general, sports mass events, football matches and arts and entertainment mass events.

The authors of this text are interested only in a narrow range of security breaches at mass events discussed on the basis of the legal analysis of the crimes specified in the Criminal Code and the Law on the Security of Mass Events. The first version of this specific Law that virtually revolutionized Polish legislation was introduced in 1997. In the opinion of Gozdor, this law was enacted in response to the need of the hour, and the legal solutions adopted therein were an outcome of many events that had taken place at football stadiums, first and foremost, as well as during rock concerts. Certainly among the events that triggered this determined legislative action regarding the matter of security and order during mass events were the fire during a concert in the Gdansk Shipyard hall on November 11, 1994, which killed 7 people, and injured more than 300, and several hundred hooligan riots during football matches in 1995-1997 (Gozdór, 2008: 33). Further experiences, after this Law and its assumptions regarding the organizer's responsibility for the security of a mass event was introduced in 1997, brought about further changes, and eventually led to the adoption of a new law in 2009. The catalog of prohibited acts was precisely itemized at that time, including the following:

- Article 58(1-3): organization of a mass event without the required permit or contrary to the conditions set out in the permit, conducting a mass event contrary to the prohibition issued; 
- Article 59(1): carrying or possessing weapons, pyrotechnic articles, dangerous materials or other dangerous objects or explosives;

- Article 60(1): breaking into the area of sports competitions, e.g. pitch invasion;

- Article 60(1a): breaking into the area of a mass event, e.g. a facility, a stadium;

- Art. 60(2): throwing objects that may pose a threat to life or health;

- Article 60(3): violating the bodily integrity of a member of the security or information services,

- Article 60(4): using an object (clothing) to impede identification when committing crimes under Article 60(1-3);

- Article 60(5): assaulting a member of the security or information services;

- Art. 61: provoking supporters to dangerous behaviors (responsibility of e.g. competition announcer, etc.) (Ustawa, 2009).

Chart 1. Mass events protected by the police, 2014-2017

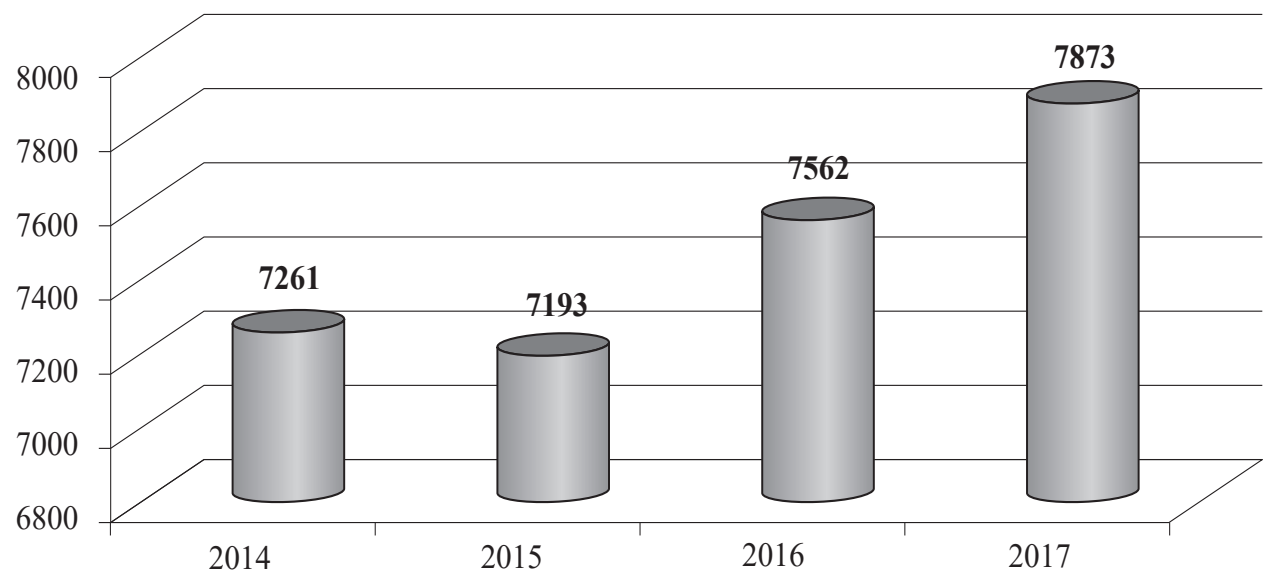

Source: Biuro Główny Sztab KGP: Raport o stanie bezpieczeństwa imprez masowych 2017 r.

It can easily be noted that the above catalog of offenses is related to those threats that are not penalized by the Criminal Code or other laws stipulating criminal provisions. The provisions in the Law on the Security of Mass Events were intended to create the conditions to ensure the proper conduct of sports events and force fans to behave in the desired manner, which, in this case, meant behavior consistent with the expectations of the mass event's organizer and of the officers responsible for security and public order. The authors of the legislation proposed, and of its further amendments were aware that the participants of mass events committed a number of other offenses such as fights, assault and hate crimes, which were covered by separate regulations and did not require penalties to be stipulated in this regulation. Unfortunately, neither the reports of the Ministry of the Interior on the state of security in Poland nor the statistics of the General Police Headquarters present the analysis of specific phenomena involving the security of mass events in relation to e.g. 'other crimes,' including hate crimes, or crimes committed in connection with mass events. The reports present only aggregate statistics that are, in fact, very general. This is a major weak- 
ness of the reports and statistics presented by the Office of the Main Police Staff of the General Police Headquarters. ${ }^{15}$

Therefore, although this threat analysis is only partial, the authors believe it should start with the number of mass events organized in Poland.

The aggregated data indicates that the number of mass events protected and safeguarded by the police in 2017 increased by 311 compared to 2016; and that their number increased by 612 over a period of four years. Since this article concerns mainly football matches, the data on the share of football matches in the total number of mass events in Poland is presented (Chart 2).

Chart 2. Percentage distribution of mass events

\section{PERCENTAGE DISTRIBUTION OF DIFFERENT MASS EVENTS ORGANIZED IN 2017}

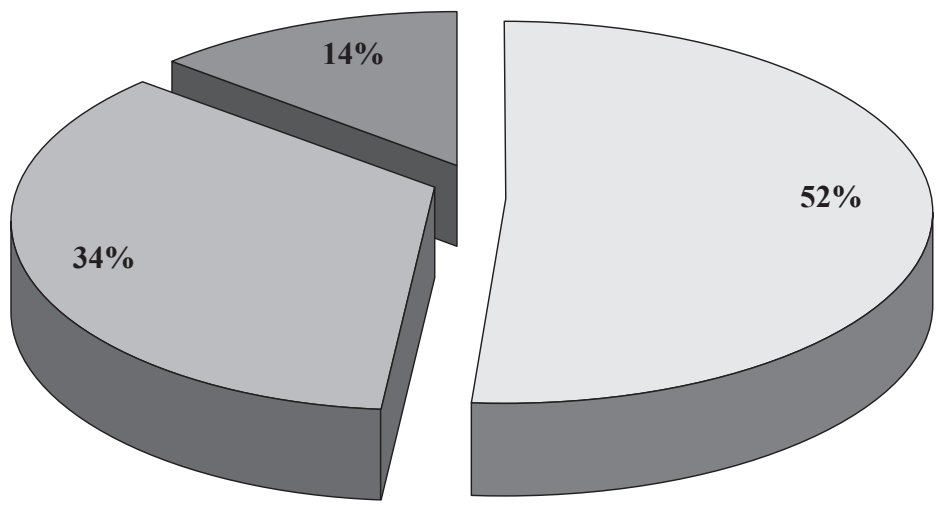

arts and entertainment mass events

sports mass events

football matches

Source: Biuro Główny Sztab KGP: Raport o stanie bezpieczeństwa imprez masowych 2017 r.

Without a doubt, it is safeguarding the barely 14 percent of all mass events organized in Poland, namely football matches, that poses the most serious challenge to the police. According to the above report, in 2017 the police had to delegate 325,695 police officers to safeguard mass events; as many as 210,027 of them performed their tasks in connection with football matches. This proportion speaks for itself: these 14 percent of all mass events absorbed $2 / 3$ of the total police forces required to provide security.

The analysis of the most dangerous crime-related behaviors which are a direct threat to security and public order is presented below. The report states that 1,381 crimes were recorded in connection with mass events organized in 2017, which is an increase by 378 compared to 2016. The largest number of crimes occurred during the events -939 , and before events - 354; 34 incidents took place after the events and 54 during the participants' travels. Among the crimes recorded in 2017, 801 were related to arts and enter-

${ }^{15}$ The task of the Main Police Staff of the General Police Headquarters is to manage current information on the state of security and public order and to take action in the event of serious threats to public security and order; http://www.policja.pl/pol/kgp/glowny-sztab-policji (15.02.2018). 
tainment mass events ( 58 percent of the total), 529 to football matches ( 38 percent of the total), and 51 to sports mass events (4 percent) (Raport KGP, 2017). To sum up, football matches, that account for only 14 percent of all events, generate as many as 38 percent of crimes recorded in 2017 committed in connection with mass events.

Specialists ensuring appropriate conditions for the safe preparation and conduct of a mass event divide such preparations into individual stages or phases. It appears to be a bit of a joke that police officers use very simple names for the stages of a comprehensive process of preparations and implementation, namely before, during and after. Each of them has its own peculiar character and threats, so the authors of the report also determined the numbers of crimes committed during these stages. It is reported that most crimes are committed during mass events, but the large proportion (around $1 / 2$ to $1 / 3$ ) occurring 'before' makes this stage dangerous as well (Chart 3 ). The total number of crimes committed in 2017 amounted to 529 acts, which was an increase by 12 percent compared to 2016 . The number of offenses committed in connection with football matches is considerably higher and equally dangerous. According to the authors of the report, in 2017, this number amounted to 7,462 of criminal acts (60 percent more than in 2016). The huge shortcoming of the report analyzed here is that it unfortunately does not present the crimes and offenses by individual categories. Therefore, we do not know which crimes are committed most often. This significantly limits the possibilities of drawing conclusions and counteracting the problems. In other words, we know that 'part of the society is ill,' but since the name of the disease remains unknown, the actions taken may be inadequate and thus ineffective.

Chart 3. Crimes committed in connection with football matches by individual stages of preparation and implementation

\section{CRIMES COMMITTED}

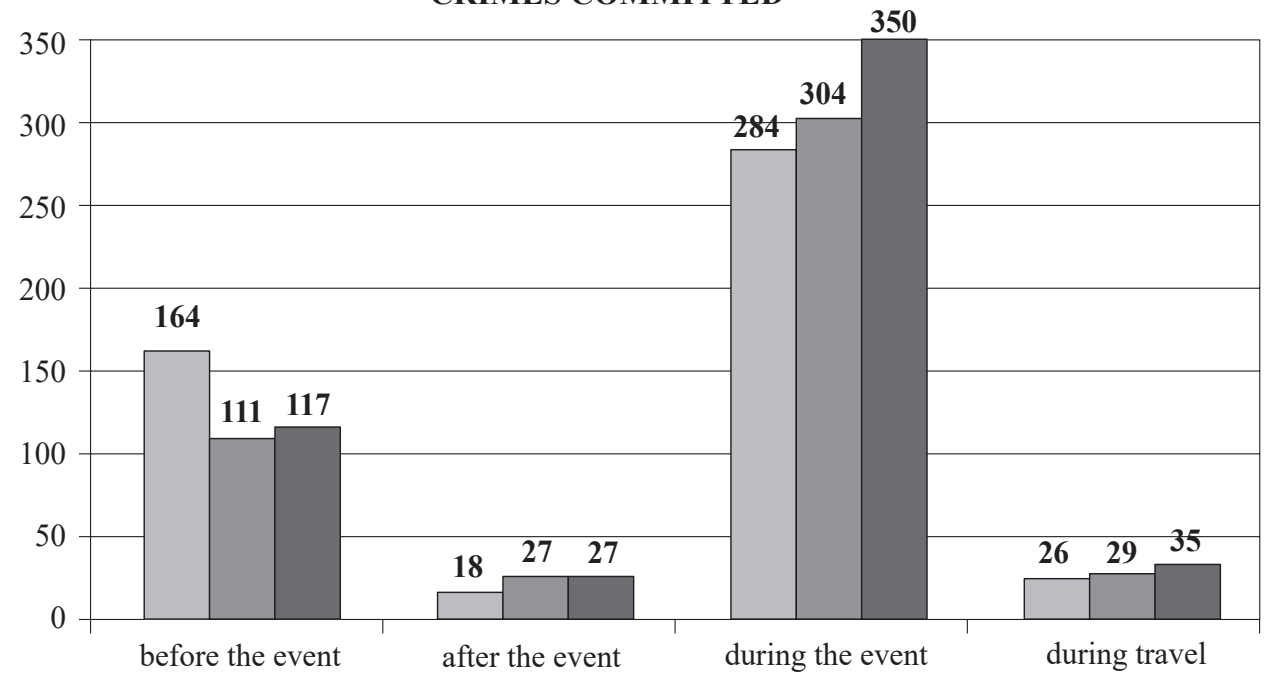

$2015 \square 2016 \square 2017$

Source: Biuro Główny Sztab KGP: Raport o stanie bezpieczeństwa imprez masowych 2017 r. 
Unfortunately, the security of Polish mass events has not changed much. The instances of hatred, violence, crimes, offenses and contempt for the law continue to characterize this area of public life. It therefore seems quite obvious that new solutions need to be sought to ensure efficient measures of opposing this pathology; alternatively, the solutions that have produced the desired effects in Poland and elsewhere should be implemented and developed with great care. Dialogue with football fans should not be abandoned either, based on factual arguments presented by their clubs, security services and the police. However, this dialogue is possible only with those who do not break the law. It should be absolutely clear for the groups of 'stadium thugs' that the police will show 'zero tolerance.' Additionally, the above-discussed function and premises of the work of police spotters, tested during Euro 2012, should be continued and developed so as to relatively urgently respond to the changing demands for their work from the police, event organizers, football clubs and supporters. The 2014 study conducted by one of the authors of this article among police officers, including the group of police spotters in particular, was intended to examine the research problem formulated in the following way: does the function [of police spotters] stand a chance to continue operating in Poland? The author described the results of his study in this group as follows: "In light of the research it seems obvious that introducing the function of spotters was justified as a necessary element of safeguarding the final tournament in Poland. In addition, it should be observed that training needs have been properly diagnosed and a good training program has been prepared. Considering the above, it has to be admitted that this solution stands a great chance of improving the effectiveness of police tasks in safeguarding mass events in the future. On the basis of international, and the Polish experience, gathered mainly in the course of the Euro 2012 Championships, and the results of the research conducted, an even more categorical conclusion can be drawn that this solution will contribute to improving the safety of mass football events in Poland" (Jarczewski, 2015: 215). This was an enthusiastic vision based on factual research results. For unknown reasons, however, after the final tournament of Euro 2012, the role of spotters was not developed, and currently this group of officers operates almost exclusively in relation to the matches of the national Polish football team. This is, of course, important but not sufficient.

Combating stadium crime cannot have only a local dimension. It should be conducted globally, not only in terms of close neighborly relations between culturally similar countries, or within communities such as the European Union, although the EU does carry out systematic work and analyses in this field. Even greater determination and joint activities of all countries that want to get involved in combating this negative phenomenon is required. Without a doubt, national legislation should be analyzed with respect to the system of current legal standards, both as concerns specific solutions applied for mass events and a number of other legal provisions, including the criminal codes. Introducing criminal responsibility for mere participation in a collective violation of public order and security, or in a hooligan incident, and even for belonging to 'hooligan squads' should be considered, as is the case of responsibility for membership of an organized criminal group. The law should function as a stabilizing and dynamic 
element at the same time. For this, however, a full analysis of compliance with the law is needed to propose new directions for legal solutions. Such a law could protect the existing, tried and tested solutions, or introduce new solutions found necessary given the emerging threats. An effective law should, after all, serve to eliminate behaviors that threaten protected values. The broadly understood safeguarding of mass events also encompasses legally protected goods that are important from the point of view of the individual, such as life, health, property, dignity, honor, bodily integrity and freedom. Thus, to perform an accurate analysis, meticulous collection of the data on crimes committed in connection with mass events is required; including those that violate the Law on Security of Mass Events, as well as hate crimes and common criminal acts in the form of attacks on life, health and property. The analysis of these crimes would make it possible to monitor threats much more effectively, especially in the field of crimes committed against the security of mass events and in particular of football matches.

The efficiency of actions in the area of security depends largely on the quality of legislative work, verification of strategic goals and their appropriate hierarchy, as well as on the proper (resulting from real needs) allocation of specific resources to these goals (Lisiecki 2008: 87). Over the last decade, the optimization of police activities to ensure the safety of mass events has been a strategically important priority of the Chief of the Police (Biuletyn, 2016). This means that the police realize that this is a significant problem. Nevertheless, the question of whether the actions taken are sufficient will always remain. The police cannot be alone in its endeavors. Firmly combatting racism, xenophobia, hate speech and all crimes that should jointly be named 'stadium crime' whenever they occur at such events, should also be supported by the leading politicians from the countries that accept this challenge. If the aim of politicians' actions is to win the favor of a specific electoral group originating from the group of football hooligans, they will more than likely paralyze the work of the law enforcement authorities, in particular the police and even the prosecutor's office, rendering police efforts fruitless. One should be aware that it is impossible to simply 'make friends' with some radical hooligan groups. A lack of consistent actions and systemic solutions will require law enforcement authorities to launch a package of tried, tested and effective actions of law to combat this radical community from scratch, over and over again. In 2010 and 2013, Prime Minister Donald Tusk gave priority to combating stadium hooliganism (Premier, 2013). In 2018, Prime Minister Mateusz Morawiecki followed suit, announcing that "ministers will carry out a quick analysis of European solutions to prevent excesses of football hooligans. The Prime Minister added that he would seek to eliminate this phenomenon. He did not rule out resorting to drastic solutions in Poland, similar to those Great Britain used in the past" (Premier, 2018). However, practitioners dealing with the security of mass events know that declarations need to be accompanied by consistent actions rather than isolated spurts aiming to gain political profit. A long-term policy is required - a well-thought-out strategy - and a consistent battle against this negative image that is painted by extreme groups of football hooligans in Poland.

Summing up, the analysis of the statistics and the knowledge obtained directly from police circles, as well as media coverage of the issues examined, indicate that the 
hypothesis adopted has been confirmed that, although public security authorities have been implementing a wide range of measures, crime and deep-rooted hatred towards enemy clubs and ideological opponents continue to be a hallmark of football fan circles and thus of some mass events organized in Poland. The inconsistent continuation of good practices adopted in the past, perceiving the problem only in terms of isolated incidents, and the lack of statistics that would help to prepare precise scientific analyses, all require moderation in predicting positive changes in this narrow area of public security.

\section{REFERENCES}

Biuletyn Informacji Publicznej (2016), Priorytety Komendanta Głównego Policji na lata 2016-2018, http://bip.kgp.policja.gov.pl/kgp/priorytety-kgp/22565,Priorytety-Komendanta-GlownegoPolicji-na-lata-2016-2018.html (09.03.2018).

Chlebowicz P. (2009), Chuligaństwo stadionowe. Studium kryminologiczne, Warszawa.

Gozdór G. (2008), Bezpieczeństwo imprez masowych. Komentarz, Wyd. C.H. Beck, Warszawa.

Jarczewski W. (2017), Koordynacja bezpieczeństwa imprez masowych w praktyce i rozwiazaniach prawnych, „Biuletyn Strategiczny”, No. 10, Poznań. DOI : 10.14746/ps.2017.1.14.

Jarczewski W. (2015), doctoral dissertation: Wykorzystanie potencjału polskiej Policji w obszarze zabezpieczenia imprez masowych zgromadzonego $w$ ramach przygotowań do turnieju finałowego Euro 2012, Szczytno.

Komenda Główna Policji - prezentacja z narady zastępcy komendanta głównego Policji z 13 lipca 2011 r. w Sułkowicach, przygotowana przez Główny Sztab Policji KGP (author’s archive).

Kraków: nasze miasto, atak z maczetami w Prokocimiu (2013) http://krakow.naszemiasto.pl/artykul/ krakow-atak-z-maczetami-w-prokocimiu-ofiara-lezala-w-kaluzy,1865761, galop,t,id,tm. html (06.02.2018).

Kraków: nasze miasto, pseudokibice Cracovii przed sądem za atak na sympatyków Wisty (2015), http://krakow.naszemiasto.pl/artykul/krakowpseudokibice-cracovii-przed-sadem-za-atakna,3325761, art,t,id,tm.html (2018).

Kroczek A., Bińkowska M. (2014), Patologie społeczne jako zagrożenia cywilizacyjne omówione na wybranych przykładach, in: Prawne, instytucjonalne i społeczne uwarunkowania bezpieczeństwa, (eds.) S. Bębas, A. Gołębiowski, Wyższa Szkoła Handlowa, Radom.

Kwaśniewski J. (1976), Koncepcja podkultur dewiacyjnych, in: Zagadnienia patologii społecznej, (ed.) A. Podgórecki, Warszawa.

Lipczyński A. (2007), Zjawisko chuligaństwa na stadionach świata w świetle różnych teorii, http:// www.psychologia.net.pl/artykul.php?level=301 (07.09.2018).

Lisiecki M. (2008), Zarządzanie bezpieczeństwem - wyzwania XXI wieku, Wydawnictwo Wyższej Szkoły Zarządzania i Prawa im. Heleny Chodkowskiej, Warszawa.

Mikosza P. (2010), Charakterystyka działań wybranych nieformalnych grup kibiców, in: Przestępczość stadionowa. Etiologia. Fenomenologia, Przeciwdziałanie zjawisku, (eds.) W. Pływaczewski, J. Kudrelek, Szczytno.

Mikosza P. (2016), Uczestnicy imprez masowych, in: Zarządzanie bezpieczeństwem imprez masowych i zgromadzeń publicznych, wymiar organizacyjno-prawny, (eds.) M. Napelski, J. Struniawski, Szczytno. 
Piotrowski P. (200), Szalikowcy. O zachowaniach dewiacyjnych kibiców sportowych, Wydawnictwo Adam Marszałek, Toruń.

Pływaczewski W. (2012), Mowa nienawiści jako komponent tak zwanej przestępczości stadionowej, in: Przestępczość stadionowa. Diagnoza i przeciwdziałanie zjawisku, (eds.) W. Pływaczewski, B. Wiśniewski, Szczytno.

Premier Morawiecki (2018), Specjalny zespół w MSWiA do walki z pseudokibicami. Premier nie wyklucza drastycznych rozwiazań, https://www.polskieradio.pl/5/3/Artykul/2128523,Specjalnyzespol-w-MSWiA-do-walki-z-pseudokibicami-Premier-nie-wyklucza-drastycznych-rozwiazan (17.03.2019).

Premier Tusk (2013), Z bandytami trzeba walczyć skutecznie, niekiedy brutalnie, http://wyborcza. pl/1,76842,14466442,Premier_Tusk_Z_bandytami_trzeba_walczyc_skutecznie_html (14.02.2017).

Raport o bezpieczeństwie imprez masowych z 2017 r., p. 8.

Sadowska J. (2011), Młodzież polska lat 60. i 70. - próba charakterystyki postaw, dążén, obszarów zainteresowań i aktywności, in: Spoteczeństwo PRL. Historia. Kultura. Pamięć, (eds.) S. Jankowiak, D. Skotarczak, I. Skórzyńska, Instytut Historii UAM, Poznań.

Telewizja Republika (2017), Skandal! Atak kiboli Legii na piłkarzy po porażce z Lechem Poznań, http://telewizjarepublika.pl/skandal-atak-kiboli-legii-na-pilkarzy-po-porazce-z-lechempoznan,54678.html (06.02.1018).

Ustawa z 20 marca 2009 r. o bezpieczeństwie imprez masowych (2009), Dz. U. 2009, Nr 62, poz. 504.

Ustawa z dnia 6 czerwca 1997 r. Kodeks karny (1997), Dz. U. 2018, poz. 1600, 2077.

Zalewska M. (2010), Subkultura „szalikowców” w Polsce, in: Przestępczość stadionowa. Etiologia. Fenomenologia. Przeciwdziałanie zjawisku, (eds.) W. Pływaczewski, J. Kudrelek, Szczytno.

\begin{abstract}
Crime and hatred have been a permanent part of mass events organized in Poland. The situation is the most difficult in the case of football matches, especially at the national level. Despite legal changes and many measures adopted by sports clubs, the police and other institutions, not only has the situation not changed but there are symptoms of its deterioration. It is extremely worrying that these informal groups form structures that operate following the principles characteristic of organized crime. The subject of study in this article are the phenomena of crime and hatred occurring at mass events organized in Poland; its purpose is to identify the causes and present conclusions regarding necessary actions, based on an analysis of statistics and reports. Methods characteristic of theoretical studies have been employed developing this study, as well as the results of surveys conducted in 2014. The basic research problems involve finding answers to the following questions:

- Did the determination of police in ensuring the safety of the EURO 2012 final tournament calm the mood and improve security of mass events?

- What is the current scale of crime, hooligan acts and collective violations of security and public order in relation to mass events organized in Poland today?

- Are the solutions in this area systemic, durable and consistent?

The hypothesis was that, although public security authorities have been implementing a wide range of measures, crime and deep-rooted hatred towards enemy clubs and ideological opponents continue to be a hallmark of football fan circles and thus of some mass events organ-
\end{abstract}


ized in Poland. The inconsistent continuation of good practices adopted in the past, perceiving the problem only in terms of isolated incidents, and the lack of statistics that would help to prepare precise scientific analyses, all require moderation in predicting positive changes in this narrow area of public security.

Keywords: crimes, hatred, mass events, security, police, supporters, football

\section{SPOLECZNE UWARUNKOWANIA ZJAWISK PRZESTĘPCZOŚCI I NIENAWIŚCI W PRZESTRZENI MASOWYCH IMPREZ SPORTOWYCH W POLSCE}

\section{STRESZCZENIE}

Przestępczość i nienawiść mają swoją ugruntowaną pozycję w przestrzeni imprez masowych organizowanych w Polsce. Najtrudniejsza sytuacja dotyczy rozgrywek piłki nożnej, zwłaszcza szczebla krajowego. Mimo zmian prawnych i wielu przedsięwzięć podejmowanych przez kluby, Policję i inne instytucje, sytuacja nie ulega zmianie, co więcej pojawiają się symptomy jej pogarszania. Niezwykle niepokojące jest to, że te nieformalne grupy tworzą struktury funkcjonujące na zasadach charakterystycznych dla przestępczości zorganizowanej. Przedmiotem badań niniejszej publikacji były zjawiska przestępczości i nienawiści pojawiające się w przestrzeni imprez masowych organizowanych w Polsce, celem natomiast określenie przyczyn i przedstawienie wniosków dotyczących koniecznych działań, na podstawie analizy, dokonanej przez pryzmat statystyk i dokumentów sprawozdawczych. Wykorzystano metody charakterystyczne dla badań o profilu teoretycznym, przywołano też wyniki badań ankietowych prowadzonych w 2014 r. Podstawowe problemy badawcze dotyczyły poszukiwania odpowiedzi na następujące pytania:

- Czy determinacja działań Policji w zapewnieniu bezpieczeństwa turnieju finałowego EURO 2012 przyniosła uspokojenie nastrojów i poprawę bezpieczeństwa w obszarze imprez masowych?

- Jak przedstawia się obecnie skala przestępczości, czynów chuligańskich oraz zbiorowych naruszeń bezpieczeństwa i porządku publicznego w związku z organizowanymi imprezami masowymi w Polsce?

- Czy działania w tym obszarze mają charakter systemowych, trwałych i konsekwentnych rozwiązań?

Hipoteza zakładała: że, mimo podejmowania, przez organy bezpieczeństwa publicznego, szeroko zakrojonych działań, stan przestępczości i głęboko zakorzeniona nienawiść, do zidentyfikowanych przeciwników klubowych i ideologicznych, są ciągle znakiem rozpoznawczym środowisk kibolskich uczestniczących w części imprez masowych w Polsce. Brak kontynuacji dobrych rozwiązań, dostrzeganie problemu jedynie przez pryzmat zaistniałych incydentów, brak części danych statystycznych dających możliwość przygotowania precyzyjnych analiz naukowych, każą zachować umiar w przewidywaniu pozytywnych zmian w tej wąskiej przestrzeni bezpieczeństwa publicznego.

Słowa kluczowe: przestępstwa, nienawiść, imprezy masowe, bezpieczeństwo, Policja, kibice, piłka nożna 
